\title{
HAMA MANGROVE DI KECAMATAN BATU AMPAR, KABUPATEN KUBU RAYA, KALIMANTAN BARAT
}

\author{
Mangrove Pests at Batu Ampar, Kubu Raya, West Kalimantan \\ Noor Farikhah Haneda dan Mohamad Suheri \\ Departemen Silvikultur, Fakultas Kehutanan IPB
}

\begin{abstract}
Mangrove ecosystem is a complex tropical forest ecosystem that is able to live and to adapt in coastal environments. Unfortunatelly, its existence is vulnerable to the environmental change. Unless utilization of mangrove forest is not followed by enrichment and rehabilitation, it will lead to degradation of logged-over land such as pest and disease infestation. The pest study was conducted in mangrove stands in PT. Bina Ovivipari Semesta (BIOS), Kubu Raya, West Kalimantan. The result of study consisted of three sample plots obtained from the average of mangrove pest on the cutting area of 2017 (93.33\%), attack intensity (28\%). Additionally, the average of cutting area of 2012 were at 91.95\% and attack intensity (29\%) while the protection forest obtained the average of attack at $79.23 \%$ and attack intensity (21.87\%). The results of pest identification of mangrove arboretum were 9 pests, including pagoda bagworm (Pagodiella spp.), bagworm (Acanthopsyche sp.), krama / tree climbing crab (Episesarma spp.), nacerdes beetle (Xanthochroa sp.), aphid (Prociphilus tessellatus), barnacles (Balanus amphitrite), snails (Gastropoda Class), cobwebs, leatherleaf slugs (Vaginula bleekeri).
\end{abstract}

Key words: Kubu Raya, Mangrove, Pagodiella spp., PT. BIOS

\section{PENDAHULUAN}

\section{Latar Belakang}

Hutan adalah suatu kesatuan ekosistem berupa hamparan lahan berisi sumberdaya alam hayati yang didominasi jenis pepohonan dalam persekutuan dengan lingkungannya, yang satu dengan yang lain tidak dapat dipisahkan (Undang-Undang No 41 Tahun 1999). Hutan mangrove merupakan suatu tipe hutan yang tumbuh di daerah pasang surut yang tergenang pada saat pasang dan bebas dari genangan pada saat surut dengan komunitas tumbuhannya bertoleransi terhadap garam (Kusmana et al. 2005).

Pemanfaatan hutan magrove apabila tidak diikuti dengan kegiatan pengayaan atau rehabilitasi akan menyebabkan degradasi pada lahan bekas tebangannya sehingga berpotensi menimbulkan bencana alam. Penerapan setiap aspek silvikultur perlu dilakukan agar pemanfaatan hutan dapat dilakukan secara berkelanjutan tanpa mengurangi produktivitasnya. Salah satu aspek yang perlu diperhatikan dalam mendukung rehabilitasi yang mengarah pada regenerasi adalah aspek persemaian. Pembangunan persemaian tak jarang terganggu oleh serangan hama dan penyakit yang dapat menyebabkan terjadinya kegagalan dalam pembangunan persemaian, maka dari itu aspek kesehatan di persemaian khususnya serangan hama terhadap tanaman jenis mangrove perlu diperhatikan melalui penelitian survei hama yang dilaksanakan di PT. Bina Ovivapri Semesta, sebagai salah satu pemegang Izin Usaha Pemanfaatan Hasil Hutan Kayu Hutan Alam (IUPHHKHA) di Kabupaten Kubu Raya, Kalimantan Barat.
Penelitian ini bertujuan untuk mengetahui jenis gangguan hama hutan mangrove di tegakan serta mengetahui insidensi serangan dan intensitas serangannya, mengidentifikasi jenis hama yang menyerang jenis-jenis mangrove di arboretum dan tegakan mangrove, serta membandingkan jenis hama yang ditemukan di tegakan dan di areal arboretum hutan mangrove.

\section{METODE PENELITIAN}

\section{Waktu dan Tempat}

Penelitian dilaksanakan pada bulan Februari 2016 sampai Maret 2016 di areal PT. Bina Ovivipari Semesta (BIOS) yang terletak di Kabupaten Kubu Raya, Kalimantan Barat.

\section{Alat dan Bahan}

Alat dan bahan yang digunakan dalam pengambilan data materi khusus adalah kompas, alat tulis, kamera digital, pita meter, spesimen serangga, alkohol 70\%, laptop dan MS Excel 2013, dan MS Word 2013.

\section{Metode Penelitian}

\section{Pengambilan Data di Lapangan}

Pengambilan data di lapangan dilakukan secara purposive sampling berjumlah tiga petak contoh yakni, Petak Tebangan Tahun 2017, Petak Tebangan Tahun 2012, serta petak hutan lindung. 
Kegiatan identifikasi pada arboretum mangrove seluas $2500 \mathrm{~m}^{2}$ dengan metode sensus dan mengambil sampel jenis hama dan bentuk kerusakannya.

\section{Pembuatan Plot}

Masing-masing petak pengamatan dibuat plot contoh berukuran $10 \mathrm{~m}$ x $10 \mathrm{~m}$ sebanyak 9 plot yang disusun secara purposive sampling sehingga total jumlah seluruh plot pada ketiga petak pengamatan berjumlah 27 plot.

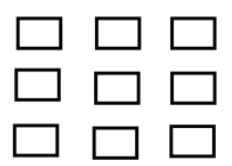

Gambar 1 Plot pengukuran kerusakan hama di tegakan mangrove.

\section{Analisis Data}

Untuk mengetahui tingkat kerusakan di tegakan mangrove dilakukan perhitungan Insidensi Serangan dan Intensitas Serangan.

Menghitung insidensi serangan tanaman dengan rumus:

Ket:

$$
\text { Insidensi serangan }=\frac{n}{N} \times 100 \%
$$

$\mathrm{n}=$ jumlah tanaman yang terserang

$\mathrm{N}=$ jumlah tanaman yang diamati dalam satu plot contoh

Menghitung intensitas serangan hama pada tanaman dengan rumus:

$$
\text { Intensitas serangan }=\frac{\sum\left(n_{i} \times v_{j}\right)}{N \times Z} \times 100 \%
$$

Ket:

ni $=$ jumlah bibit tanaman yang terserang pada klasifikasi tertentu

$\mathrm{vj}=$ nilai pada klasifikasi tertentu

$\mathrm{N}=$ jumlah total bibit tanaman yang diamati dalam satu petak contoh

$\mathrm{Z}=$ nilai tertinggi klasifikasi

Kriteria kerusakan pohon yang disebabkan oleh serangan hama dapat dilihat pada Tabel 1.

Tabel 1 Kriteria kerusakan yang disebabkan hama dan

\begin{tabular}{|c|c|c|c|}
\hline Klasifikasi & Deskripsi & $\begin{array}{l}\text { Intensitas } \\
\text { serangan }\end{array}$ & $\begin{array}{l}\text { Kategori } \\
\text { serangan }\end{array}$ \\
\hline 0 & $\begin{array}{l}\text { Tidak ada } \\
\text { kerusakan } \\
\text { pohon }\end{array}$ & 0 & Sehat \\
\hline 1 & $\begin{array}{l}\text { Bagian pohon } \\
\text { yang rusak/ } \\
\text { terserang 1- } \\
25 \% \text { dari } \\
\text { jumlah } \\
\text { seluruhnya }\end{array}$ & $>0-25 \%$ & Ringan \\
\hline
\end{tabular}
tanaman

\begin{tabular}{clcc}
\hline Klasifikasi & \multicolumn{1}{c}{ Deskripsi } & $\begin{array}{c}\text { Intensitas } \\
\text { serangan }\end{array}$ & $\begin{array}{c}\text { Kategori } \\
\text { serangan }\end{array}$ \\
\hline 2 & $\begin{array}{c}\text { Bagian pohon } \\
\text { yang rusak/ } \\
\text { terserang 26- }\end{array}$ & 26-50\% & Sedang \\
& $50 \%$ dari & & \\
jumlah & & \\
& seluruhnya & & \\
& Bagian pohon & $51-75 \%$ & Berat \\
& yang rusak/ & & \\
terserang 51- & & \\
& $75 \%$ dari & & \\
& jumlah & & \\
& seluruhnya & & Sangat \\
& Bagian pohon & $76-100 \%$ & \\
& yang rusak/ & & \\
terserang 76- & & \\
& $100 \%$ dari & & \\
& jumlah & & \\
& seluruhnya & & \\
&
\end{tabular}

\section{HASIL DAN PEMBAHASAN}

\section{Insidensi Serangan dan Intensitas Serangan}

Insidensi serangan merupakan tingkat kerusakan pada pohon di lapangan, sehingga dapat dijadikan acuan untuk mengetahui seberapa banyak pohon yang terserang. Intensitas serangan merupakan tingkat keparahan pada setiap pohon yang diakibatkan oleh serangan hama. Insidensi serangan dan intensitas serangan pada tegakan hutan mangrove dapat dilihat pada Tabel 2.

Tabel 2 Insidensi serangan dan intensitas serangan hama pada tegakan mangrove

\begin{tabular}{lccc}
\hline Blok tebangan & $\begin{array}{c}\text { Insidensi } \\
\text { Serangan } \\
(\%)\end{array}$ & $\begin{array}{c}\text { Intensitas } \\
\text { Serangan }(\%)\end{array}$ & $\begin{array}{c}\text { Kategori } \\
\text { serangan }\end{array}$ \\
\hline Tahun 2017 & 93.33 & 28.00 & Sedang \\
Tahun 2012 & 91.95 & 29.00 & Sedang \\
Hutan Lindung & 79.23 & 21.87 & Ringan \\
\hline
\end{tabular}

Hasil pengamatan di blok tebangan tahun 2017 diperoleh nilai rata-rata insidensi serangan sebesar 93.33\% dengan nilai intensitas serangan sebesar $28 \%$. Oleh karena itu dapat diketahui bahwa gangguan hama di petak tebang tahun 2017 termasuk kategori sedang karena memiliki nilai intensitas serangan berkisar antara $26 \%-30 \%$.

Hasil pengamatan di blok tebangan tahun 2012 diperoleh nilai rata-rata insidensi serangan sebesar 91.95\% dengan nilai intensitas serangan sebesar $29 \%$. Berdasarkan hasil ini menunjukkan bahwa serangan hama di petak tebang tahun 2012 lebih tinggi dibandingkan petak tebang tahun 2017 maupun hutan lindung, walaupun masih dalam tingkat kategori serangan hamanya sedang.

Hasil pengamatan di blok hutan lindung diperoleh nilai rata-rata insidensi serangan sebesar $79.23 \%$ dengan nilai intensitas serangan sebesar $21.87 \%$. Berdasarkan hasil ini, menunjukkan bahwa serangan hama di hutan lindung masuk dalam tingkat kategori ringan serangannya. 
Pada hutan lindung diketahui bahwa serangan hamanya lebih rendah dibandingkan dengan petak tebang tahun 2017 maupun 2012. Hal ini dapat terjadi karena pengaruh ekosistem hutannya yang masih terjaga sebagai kawasan hutan lindung. Fungsi lindung pada hutan mangrove antara lain sebagai pembentuk daratan dari bahan-bahan yang dibawa oleh banjir dan erosi, pelindung tanah-tanah terhadap erosi pantai, tempat pembiakan jenis-jenis ikan laut, sebagai habitat jenisjenis satwa misalnya burung, mamalia, reptilia, dan sebagai stabilisator perairan sehingga terjaga keadaan ekosistemnya untuk tetap mempertahankan fungsi lindung tersebut (Soeroyo 1992). Ekosistem hutan mangrove yang masih terjaga bersifat kompleks dan dinamis. Dikatakan kompleks karena disamping ekosistemnya dipenuhi oleh vegetasi mangrove, juga merupakan habitat berbagai satwa dan biota perairan. Bersifat dinamis karena hutan mangrove dapat tumbuh dan berkembang terus serta mengalami suksesi sesuai perubahan tempat tumbuh alaminya (Anwar \& Gunawan 2006). Oleh karena itu, keseimbangan hayati di hutan lindung masih tinggi sehingga belum terlalu terjadi serangan hama yang cukup berarti.

\section{Gejala di Tegakan Hutan Alam Mangrove}

Kegiatan penebangan di hutan alam mangrove merupakan salah satu penyebab terjadinya degradasi sehingga akan mempengaruhi eksosistem yang sudah berjalan secara dinamis sebelumnya. Salah satu dampak dari menurunnya keseimbangan ekosistem itu sendiri yaitu terjadinya serangan hama pada tegakan tersebut. Salah satu indikator adanya serangan hama adalah munculnya ekspresi yang ditimbulkan oleh pohon akibat serangan hama yang biasa disebut gejala. Gejala yang ditemukan di lapangan dapat dilihat pada Gambar 2.

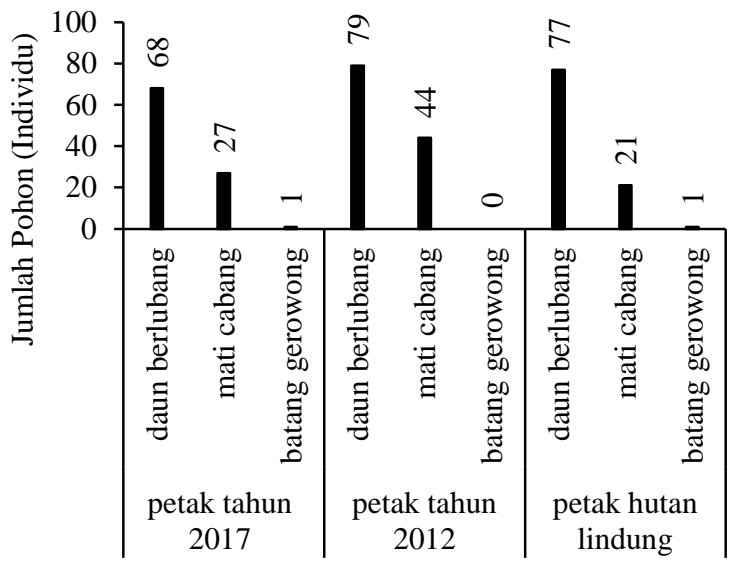

Petak Contoh

Gambar 2 Gejala serangan hama yang ditemukan di tegakan hutan mangrove berdasarkan petak contoh.

Hasil pengamatan yang dilakukan di petak tebang tahun 2017 ditemukan tiga gejala diantaranya, daun berlubang sebanyak 68 pohon, mati cabang sebanyak 27 pohon, dan batang berlubang sebanyak 1 pohon. Hasil pengamatan pada petak tebang tahun 2012 hanya ditemukan 2 gejala diantaranya, daun berlubang sebanyak 79 pohon dan mati cabang sebanyak 44 pohon. Hasil pengamatan pada hutan lindung mangrove ditemukan 3 gejala diantaranya, daun berlubang sebanyak 77 pohon, mati cabang sebanyak 21 pohon, dan batang berlubang sebanyak 1 pohon. Jumlah pohon di petak tebang tahun 2012 memiliki jumlah pohon tertinggi yang terserang dibandingkan dengan petak tebang tahun 2017 maupun hutan lindung. Jumlah gejala yang ditemukan, petak tebang tahun 2012 paling sedikit dibandingkan petak tebang tahun 2017 maupun hutan lindung karena hanya dua gejala yang ditemukan yakni, daun berlubang dan mati cabang tanpa adanya batang berlubang yang ditemukan pada petak tahun 2017 dan hutan lindung.

Gejala daun berlubang terjadi akibat serangan hama ulat kantong. Ulat kantong memakan daun sehingga menimbulkan lubang pada daun. Jenis hama ulat kantong yang ditemukan di lapangan adalah jenis Pagodiella spp. dan Acanthopsyche spp. Jenis Pagodiella spp. merupakan hama utama yang menyerang daun di tegakan hutan mangrove yang cukup besar kerusakannya, hal ini karena jenis yang banyak ditemukan di lapangan jenis ulat kantong yang memiliki ciri kantong berbentuk pagoda.

Menurut Wahid (2010), jenis paling dominan yang ditemukan di lapangan hutan mangrove, baik populasi maupun kerusakannya, adalah Pagodiella spp.. Ulat kantong Pagodiella spp. berbentuk seperti pagoda, menyerang tanaman dengan cara memakan daun pada permukaan bawah daun.

Gejala mati cabang disebabkan oleh serangan hama rayap (Prorhinotermes sp.) yang membuat rumah di sepanjang jalan batang sampai ke cabang. Serangan rayap (Prorhinotermes sp.) menyebabkan jaringan rusak pada cabang maupun batang sehingga berujung ke kematian cabang. Serangan rayap merupakan hama kedua yang cukup tinggi serangannya setelah serangan hama ulat kantong.

Jenis rayap dari genus Prorhinotermes sp. memiliki habitat di areal rawa sehingga sudah beradaptasi dengan areal air asin maupun air payau. Mereka membuat rumah di sepanjang batang sampai ke cabang, memakan habis jaringan batang sehingga menyebabkan batang berlubang. Menurut Tho (1992) rayap dari Famili Rhinotermitidae, Subfamili Rhinotermitinae, dan Genus Prorhinotermes memiliki habitat di kawasan pesisir serta areal rawa bakau.

Prorhinotermes adalah genus dari sebagian rayap tanah di wilayah tropis. Keanekaragaman terbesar ada di wilayah pesisir Asia Tenggara, sering di rawa-rawa bakau. Prorhinotermes flavus adalah salah satu dari beberapa spesies rayap yang dapat bertahan hidup di rawa-rawa bakau tergenang air, meskipun bersarang di tempat yang lembab, dapat membusukkan kayu, aktivitasnya terbatas pada tanah kering, dan lebih banyak ditemukan di rawa (Tho 1992).

Gejala lubang gerek disebabkan oleh serangan hama rayap (Prorhinotermes sp.) dan semut. Hama rayap membuat rumah di sepanjang batang sampai ke cabang, memakan habis jaringan batang sehingga membentuk lubang gerek. Serangan semut berupa sarang di bagian 
batang sehingga menyebabkan keadaan terparah yakni batang tersebut berlubang.
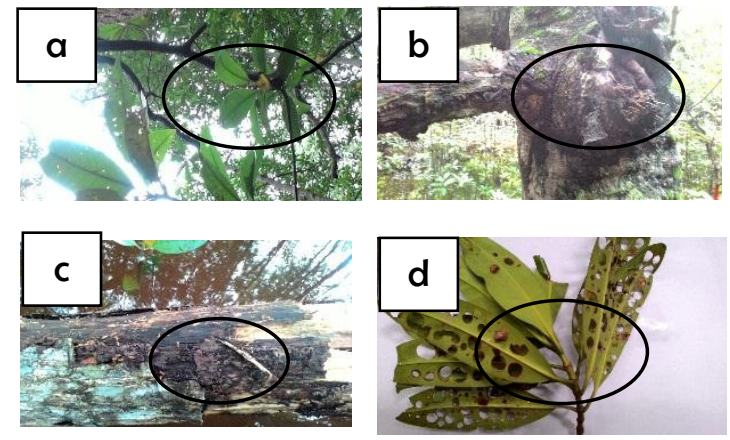

Gambar 3 Gejala serangan hama mangrove terdiri; (a) mati cabang akibat serangan hama rayap (Prorhinotermes sp.), (b) serangan hama Prorhinotermes sp. pada batang Rhizophora apiculata, (c) batang berlubang akibat diserang oleh hama rayap, serta (d) daun berlubang akibat serangan ulat kantong (Pagodiella spp.).

\section{Tanda di Tegakan Hutan Alam Mangrove}

Tanda merupakan bagian-bagian tertentu penyebab serangan hama pada suatu tanaman maupun pohon. Menurut Yunasfi (2007) tanda merupakan bagianbagian tertentu penyebab penyakit seperti fungi yang menempel pada batang pohon atau tepung berwarna putih atau hitam yang terbentuk pada permukaan daun. Tanda dapat ditemukan di batang, daun, cabang, akar dan sebagainya. Tanda dapat ditemukan berupa sarang, serbuk gerek dan serangga itu sendiri. Jumlah tanda yang ditemukan pada tegakan mangrove dapat dilihat pada Gambar 3.

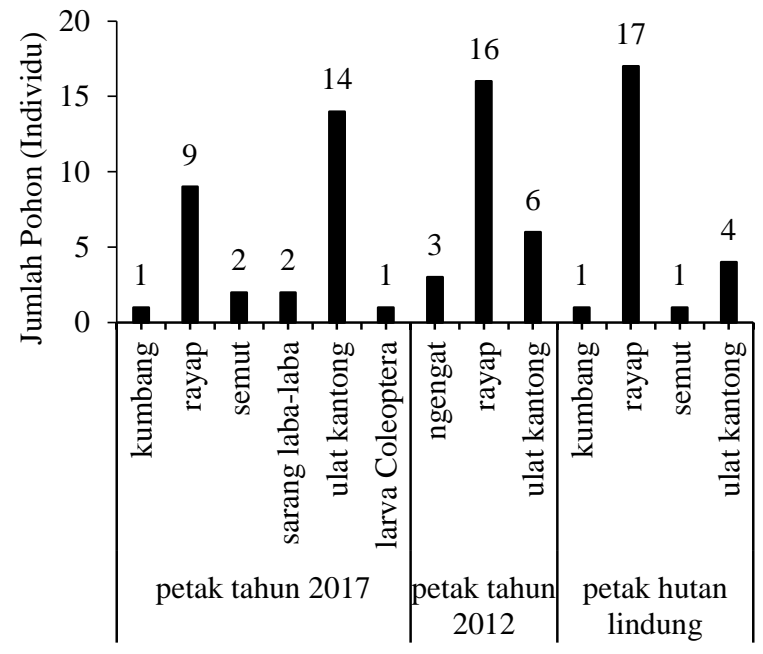

Petak Contoh

Gambar 4 Tanda yang ditemukan pada tegakan hutan alam mangrove.

Hasil pengamatan tanda di petak tebang tahun 2017 diantaranya, kumbang, rayap, semut, sarang laba-laba, ulat kantong, dan ulat batang. Tanda yang paling banyak ditemukan di petak tebang tahun 2017 adalah ulat kantong terdapat 14 pohon. Tanda lain seperti kumbang terdapat 1 pohon, sarang rayap terdapat 9 pohon, sarang semut terdapat 2 pohon, sarang laba-laba terdapat 2 pohon, serta ulat batang terdapat 1 pohon. Tanda yang ditemukan pada petak tebang tahun 2012 diantaranya, ngengat, sarang rayap, dan ulat kantong. Tanda yang paling banyak ditemukan pada petak tebang tahun 2012 adalah sarang rayap terdapat 16 pohon. Selain itu, tanda lain yang ditemukan diantaranya, ngengat terdapat 3 pohon, dan ulat kantong terdapat 6 pohon. Tanda yang ditemukan pada hutan lindung diantaranya, kumbang, sarang rayap, sarang semut, dan pohon ulat kantong. Tanda yang paling banyak ditemukan di petak hutan lindung adalah sarang rayap yakni terdapat 17 pohon. Tanda lainnya seperti kumbang terdapat 1 pohon, sarang semut terdapat 1 pohon, dan ulat kantong terdapat 4 pohon.

Tanda yang ditemukan di petak tebang tahun 2017 paling banyak dibandingkan dengan petak tebang tahun 2012 maupun di hutan lindung. Tanda yang hanya ditemukan pada petak tebang tahun 2017 yakni sarang laba-laba dan larva Coleoptera, sedangkan petak tebang yang paling sedikit ditemukan tandanya adalah petak tebang tahun 2012 yaitu ngengat, sarang rayap, dan ulat kantong. Pada petak ini juga ditemukan ngengat yang hanya ada di petak tebang tahun 2012. Tanda yang paling banyak ditemukan pada ketiga petak tersebut adalah sarang rayap dan ulat kantong. Hal ini sesuai dengan data gejala yang ditemukan di lapangan yakni banyak yang mengalami daun yang berlubang akibat serangan ulat kantong serta cabang atau batang yang diserang oleh rayap sehingga mengalami kerusakan dengan gejala mati cabang dan batang berlubang gerek.
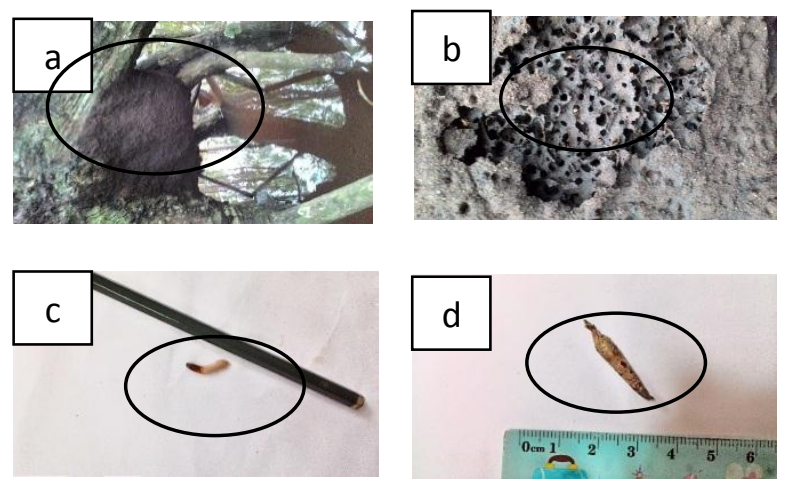

Gambar 5 Tanda yang ditemukan di tegakan mangrove terdiri; (a) lubang gerek rayap (Prorhinotermes sp.), (b) sarang semut, (c) larva Coleoptera, dan (d) ulat kantong (Acanthopsyche sp.).

\section{Bagian Pohon yang Diserang pada Hutan Alam Mangrove}

Hasil pengamatan di petak tebang tahun 2017 ditemukan bahwa bagian yang diserang oleh serangan hama adalah daun, cabang, dan batang. Bagian yang paling banyak diserang adalah daun yakni sebanyak 50 pohon. Bagian yang lain seperti, cabang sebanyak 27 pohon, batang sebanyak 11 pohon. Bagian yang 
diserang di petak tebang tahun 2012 adalah daun, cabang, dan batang. Bagian yang paling banyak diserang adalah daun yakni sebanyak 73 pohon. Bagian yang lainnya seperti, cabang sebanyak 43 pohon, dan batang sebanyak 7 pohon. Bagian yang terserang pada hutan lindung yaitu daun, cabang, dan batang. Bagian yang paling banyak diserang adalah daun sebanyak 77 pohon, sedangkan bagian lainnya seperti cabang sebanyak 25 pohon, dan batang sebanyak 14 pohon.

Hasil pengamatan pada ketiga petak contoh diketahui bahwa bagian yang paling banyak diserang oleh hama di tegakan hutan alam mangrove adalah daun. Hal ini sesuai dengan tanda berupa hama yang cukup banyak ditemukan yaitu ulat kantong. Setelah bagian daun, bagian yang cukup banyak diserang hama adalah cabang. Hal ini sesuai dengan tanda yang banyak ditemukan yaitu serangan rayap yang membuat rumah menjalar dari batang sampai ke cabangnya.

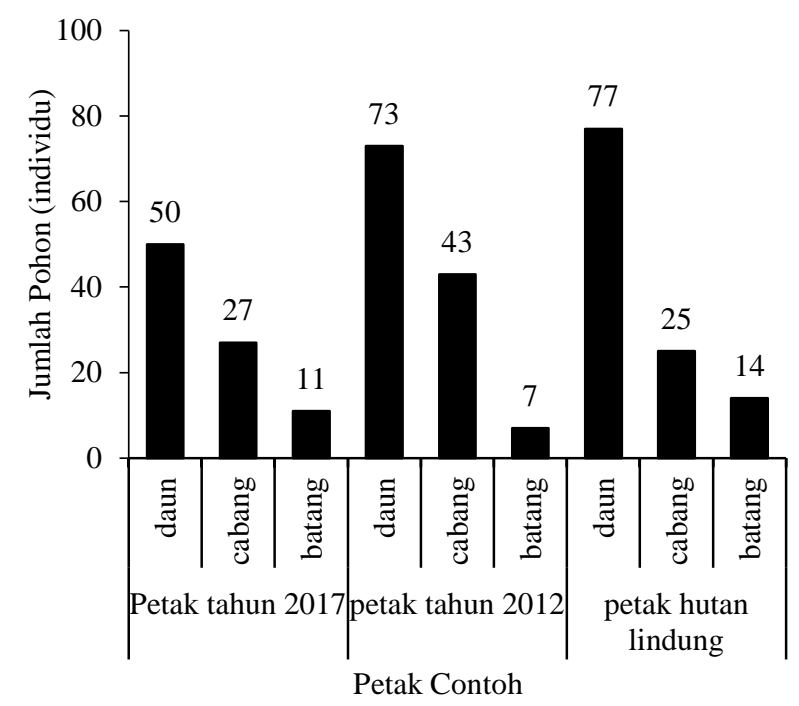

Gambar 6 Grafik serangan hama berdasarkan bagian pohon.

\section{Identifikasi Jenis Hama di Arboretum Mangrove}

Kegiatan identifikasi jenis hama di lakukan di arboretum mangrove seluas $2500 \mathrm{~m}^{2}$. Arboretum mangrove ini memang sengaja dibuat oleh bagian pembinaan hutan sebagai sarana pelestarian keanekaragaman jenis-jenis mangrove guna membantu kegiatan pendidikan maupun penelitian. Sesuai dengan pernyataan Baskara (1998) bahwa tujuan dari dibangunnya sebuah arboretum adalah untuk menjadi sarana ilmu pengetahuan khususnya di bidang kehutanan. Arboretum hutan mangrove ini ditanami jenis tanaman mangrove sebanyak 14 jenis diantaranya, bakau ( $R$. apiculata), belukap ( $R$. mucronata), api-api (A. alba), tumu (B. gymnorrhiza), tengar (C. tagal), tingi $(C$. decandra), nyirih kapur ( $X$. granatum), tancang (B. sexangela), tancang putih ( $B$. cilyndrica), kedabu ( $S$. ovata), lenggadai (B. parvifolia), perepat $(S$. alba), kandelia (C. candel), dan teruntum (L. littorea).

Hasil kegiatan identifikasi jenis hama di arboretum mangrove diketahui terdapat 9 jenis hama yang menyerang di arboretum tersebut yakni, ulat kantong pagoda (Pagodiella spp.), ulat kantong (Acanthopsyche sp.), krama (Episesarma spp.), kumbang penggerek batang (Xanthochroa sp.), kutu daun, teritip (Balanus amphitrite), keong (Gastropoda), laba-laba, dan siput tanpa cangkang (Vaginula bleekeri).

Ulat kantong merupakan hama yang paling parah serangannya pada jenis mangrove di arboretum. Jenis Ulat kantong yang menyerang terdiri dari dua jenis yakni, Pagodiella spp. dan Acanthopsyche sp.. Jenis hama ini menyerang daun jenis mangrove dengan cara memakan pada bagian bawah permukaan daun sehingga daun berlubang-lubang. Ledakan populasi ulat kantong akan menyebabkan daun gundul pada tingkat semai dan pancang pada jenis mangrove. Menurut Wahid (2010) pada pengamatannya di areal hutan tanaman mangrove pada kawasan konservasi DPL (Daerah Perlindungan Laut) Pulau Tiga di Desa Malakosa dan Sausu-Peore Kecamatan Sausu, Kabupaten Parigi Moutong jenis paling dominan yang ditemukan di lapangan baik populasi maupun kerusakannya adalah Pagodiella spp.

Krama merupakan sejenis kepiting kecil yang hidup di ekosistem mangrove. Jenis ini beberapa menjadi hama mangrove salah satunya adalah Episesarma spp. krama memakan akar dan batang yang masih muda pada tingkat semai sampai pancang pada jenis mangrove hal ini karena batang dan akar yang muda pada mangrove sangat disukai oleh beberapa jenis kepiting karena masih cukup lunak dan tergolong manis. Akibat terparah serangan oleh krama yaitu batang maupun akar menjadi berlubang dan keropos.
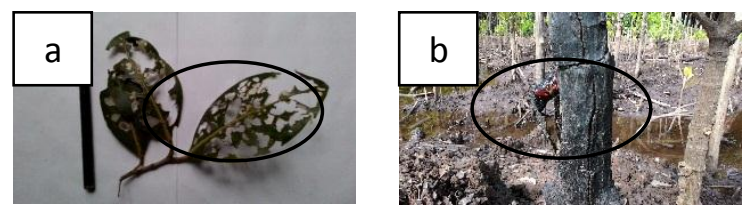

Gambar 7 Jenis hama yang menyerang di arboretum terdiri; (a) serangan hama ulat kantong (Acanthopsyche sp.) pada daun A. alba, (b) hama krama (Episesarma spp.) terdapat pada batang B. parvifolia.

Kumbang penggerek batang merupakan ordo Coleoptera dari famili Oedemeridae yang menjadi salah satu ancaman bagi jenis mangrove. Sesuai dengan namanya kumbang ini menyerang batang dengan cara menggerek. Biasanya kumbang akan menggerek batang yang masih muda karena jaringan yang masih lunak sehingga mudah untuk digerek. Akibat gerekan kumbang ini akan menyebabkan kerusakan berupa lubang gerek pada batang mangrove.

Serangga kutu daun merupakan sejenis serangga berwarna putih yang menempel pada bagian bawah daun. Jenis serangga ini termasuk ke dalam ordo Homoptera, famili Aphididae. Hama yang biasa disebut kutu daun dengan nama latin Prociphilus tessellatus akan menghisap cairan pada daun maupun ranting. Dampak terparah dari serangan hama ini adalah daun akan kering dan rontok pada jenis mangrove. Menurut Priyono (2010) bahwa kutu daun adalah sejenis serangga yang seringkali ditemui di Teluk Awur. Hama ini berwarna putih dan menyebabkan daun-daun mangrove kering. Untuk mencegah hama ini, bisa 
dilakukan dengan cara menyiram bibit-bibit mangrove dengan air laut.

Hama yang cukup banyak menyerang pada tingkat semai sampai pancang di hutan mangrove adalah dari Kelas Gastropoda, Filum Moluska. Biasanya mereka menempel pada batang sampai ke daun hingga memakan daun sampai berlubang dan gundul. Kerusakan akibat kelompok gastropoda ini menyebabkan jenis mangrove kehilangan daunnya karena habis dimakan. Diduga yang menjadi hama merupakan Filum Moluska, Kelas Gastropoda dari famili Potamididae, pendugaan ini dikarenakan hanya anggota famili ini yang ditemukan di ekosistem mangrove. Gastropoda merupakan kelas terbesar dari Filum Mollusca (Poppe \& Tagaro 2006), sebagian diantaranya hidup di ekosistem mangrove. Potamididae yang tergabung dalam Superfamili Cerithioidea merupakan satu-satunya famili Gastropoda yang semua anggotanya hanya dapat ditemukan di ekosistem mangrove (Fratini et al. 2008)
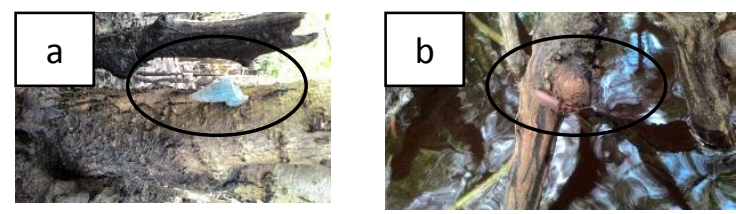

Gambar 8 (a) hama keong (Kelas Gastropoda) yang menempel pada batang $R$. apiculata, (b) hama kumbang (Xanthochroa sp.) menempel pada batang $R$. apiculata.

Hama yang cukup serius pada tingkat semai sampai pancang pada jenis mangrove salah satunya adalah teritip. Teritip termasuk ke dalam famili Crustaceae yang biasanya menempel di batang pada jenis mangrove. Balanus amphitrite bersifat hermaphrodite dan mudah berkembang biak sehingga memiliki populasi yang padat. Hewan ini bertelur dan larvanya mengembara mencari tempat yang cocok, hidupnya sessil dan tidak berpindah. B. amphitrite terkenal dengan nama teritip merupakan remis yang berbentuk kerucut dan memiliki warna keputihan (Dewiyanti \& Yunita 2013).

Hewan ini hidup menempel pada semai mangrove dan memakan kulit hingga batang mangrove yang masih muda. Oleh karena itu kerusakan yang diakibatkan oleh teritip menyebabkan kulit batang pada jenis mangrove rusak. Wibisono et al. (2006) menyatakan bahwa apabila serangan hama teritip hebat maka dapat menyebabkan kematian bibit mangrove.

Serangan hama dari Kelas Gastropoda pada jenis mangrove selain oleh keong juga ditemukan jenis siput tanpa cangkang. Jenis ini termasuk Filum Moluska, Kelas Gastropoda dengan nama latin Vaginula blekeeri atau Filicaulis bleekeri. Hewan yang biasa disebut sarasinula ataupun tropical leatherleaf slugs termasuk herbivora yang sering menjadi hama di beberapa tanaman pertanian maupuan kehutanan pada tingkat semai, salah satunya adalah jenis mangrove.
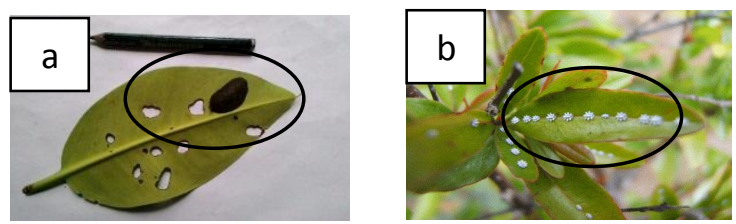

Gambar 9 (a) hama keong tanpa cangkang (Filicaulis bleekeri) memakan daun $R$. mucronata, (b) kutu daun menempel pada daun tingi (Ceriops decandra).

\section{Perbandingan Hama di Tegakan Hutan Mangrove dan Arboretum Mangrove}

Suatu keadaan ekosistem hutan akan mempengaruhi keadaan kesehatan tegakannya, salah satunya adalah dari serangan hama dan penyakit. Semakin keadaan ekosistem hutan tersebut mengalami gangguan, maka akan semakin berpeluang terjadinya serangan hama dan penyakit. Hasil pengamatan menunjukkan bahwa hama yang ditemukan di tegakan hutan mangrove lebih sedikit dibandingkan dengan hama yang ditemukan di arboretum hutan mangrove yakni, rayap (Prorhinotermes sp.), semut, ulat kantong pagoda (Pagodiella spp.), ulat kantong (Acanthopsyche sp.), ulat batang, dan kumbang penggerek batang. Sedangkan hama yang ditemukan di arboretum mangrove yakni, ulat kantong pagoda (Pagodiella spp.), ulat kantong (Acanthopsyche sp.), krama (Episesarma spp.), kumbang (Xanthochroa sp.), kutu daun, teritip (Balanus amphitrite), laba-laba, keong (Gastropoda), dan siput tanpa cangkang (Vaginula bleekeri). Hama yang ditemukan di kedua lokasi baik di tegakan maupun arboretum yaitu, kumbang penggerek batang (Xanthochroa sp.), dan ulat kantong. Hama yang hanya ditemukan di tegakan hutan mangrove yakni, rayap, semut, dan ulat batang. Sedangkan hama yang hanya ditemukan di arboretum jenis mangrove yakni krama (Episesarma spp.), scale insect, teritip (Balanus amphitrite), keong (gastropoda), dan siput tanpa cangkang (Vaginula bleekeri).

Jenis hama yang berbeda baik di tegakan maupun arboretum kemungkinan karena ada dua faktor yang mempengaruhi yaitu faktor biotik maupun faktor abiotik (lingkungan). Faktor biotik merupakan faktor dimana jenis hama yang menyerang disesuaikan berdasarkan sumber makanannya. Jenis hama yang menyerang di tegakan hutan mangrove seperti rayap, semut, dan ulat batang karena hama tersebut sumber makananya berasal dari tingkatan pohon mangrove. Rayap yang memakan selulosa pada batang mangrove ataupun batang jenis mangrove yang sudah mulai lapuk sehingga rayap hanya ditemukan di pohon-pohon mangrove. Menurut Ngatiman (2010) rayap berada pada kayu gubal dan memakan kayu gubal serta membuat lorong-lorong yang tidak beraturan. Dengan rusaknya kayu gubal ini mengakibatkan penyaluran makanan dari akar ke bagian atas tanaman terganggu, sehingga tanaman menjadi mati. Rayap tidak hanya menyerang tanaman yang masih hidup, akan tetapi menyerang batang yang sudah mati atau batang yang sudah patah/roboh. Semut membuat sarang biasanya pada pohon-pohon besar yang 
ada di tegakan hutan mangrove karena batang pohon mampu menopang sarangnya tersebut. Sedangkan ulat batang (larva Coleoptera) memang memakan kayu pada pohon dengan cara mengebor ke dalam permukaan batang.

Hama yang ditemukan di arboretum mangrove seperti, krama (Episesarma spp.), kutu daun, teritip (Balanus amphitrite), keong (Gastropoda), dan siput tanpa cangkang (Vaginula bleekeri) karena jenis hama tersebut lebih banyak menyerang jenis mangrove ketika tingkat semai sampai pancang. Di arboretum mangrove jenis yang ditanam masih termasuk kelompok pancang sehingga serangan jenis hama diatas masih cukup intensif menyerang dan ditemui di areal arboretum tersebut. Hama yang ditemukan di kedua lokasi tersebut adalah kumbang penggerek batang (Xanthochroa sp.), dan ulat kantong. Hal ini karena jenis hama ini dapat menyerang di tingkat semai sampai pohon. Ulat kantong cukup familiar menjadi hama perusak daun jenis mangrove baik di tingkat semai juga ditemukan di tegakan. Sedangkan kumbang penggerek batang (Xanthochroa sp.) disamping menyerang di batang tegakan pohon mangrove juga cenderung menyukai batang yang muda karena sel pembentuk batang di tingkat pancang masih muda dan lebih lunak sehingga lebih mudah digerek oleh kumbang tersebut.

Faktor lingkungan diduga turut mempengaruhi keberadaan jenis hama baik di tegakan mangrove maupun di arboretum. Di tegakan mangrove lebih sedikit jenis hama yang ditemukan dibandingkan dengan di arboretum diduga karena keadaan tegakan yang cukup rapat dengan tutupan tajuk yang rindang. Hal ini akan mempengaruhi suhu sekitar tegakan dalam hutan yang lebih rendah dan menciptakan iklim mikro yang masih mendekati stabil. Pengaruh lingkungan tersebut akan mempengaruhi kehidupan jenis hama. Hanya beberapa jenis hama saja yang bisa bertahan di dalam tegakan hutan mangrove dengan jumlahnya yang tidak mengkhawatirkan. Suhu udara minimum tahun 2009 terjadi pada bulan Februari dan November yakni $23^{\circ} \mathrm{C}$ dan suhu udara maksimum terjadi pada bulan Mei dengan rata - rata sebesar $24.3^{\circ} \mathrm{C}$ dengan kelembaban udara rata-rata $80-88 \%$ (BMKG Wilayah II Pontianak 2009).

Jenis hama yang ditemukan di arboretum mangrove lebih banyak, hal ini diduga karena keadaan tegakan yang masih dalam tingkat pancang sehingga tutupan tajuknya belum terlalu rindang. Kondisi ini akan mempengaruhi suhu di areal arboretum yang masih cukup hangat dengan kelembaban yang rendah sehingga memungkinkan jenis hama hidup di dalamnya. Selain itu, ketersediaan makanan berupa jenis mangrove yang cukup beragam diduga menjadi salah satu pemicu beragamnya jenis hama. Arboretum yang memang sengaja ditanam berbagai jenis tanaman mangrove sebagai koleksi biodiversity flora mangrove diduga mengundang datangnya beberapa jenis hama yang cukup banyak dibandingkan di tegakan mangrove.

\section{SIMPULAN DAN SARAN}

\section{Simpulan}

Hasil kegiatan survei hama di tegakan hutan mangrove dan di arboretum mangrove diperoleh jenis hama tegakan mangrove sebanyak 7 jenis yakni, rayap (Prorhinotermes sp.), semut, ulat kantong pagoda (Pagodiella spp.), ulat kantong (Acanthopsyche sp.), sarang laba-laba, larva coleoptera, dan kumbang (Xanthochroa sp.). Jenis hama yang ditemukan di arboretum mangrove sebanyak 9 jenis yakni, ulat kantong pagoda (Pagodiella spp.), ulat kantong (Acanthopsyche sp.), krama (Episesarma spp.), kumbang penggerek (Xanthochroa sp.), kutu daun, teritip (Balanus amphitrite), sarang laba-laba, keong (Kelas Gastropoda), dan siput tanpa cangkang (Vaginula bleekeri).

Nilai intensitas serangan hama terbesar diperoleh pada petak tebangan tahun 2012 sebesar 29\% dengan rata-rata insidensi serangan sebesar $91.95 \%$ termasuk kategori sedang dan nilai intensitas serangan hama terendah diperoleh pada areal hutan lindung sebesar $21.87 \%$ dengan rata-rata insidensi serangan sebesar $79.23 \%$ termasuk kategori ringan.

Jenis hama yang ditemukan di arboretum mangrove lebih banyak dibandingkan dengan jenis hama di tegakan mangrove hal ini diduga dipengaruhi oleh faktor biotik yakni, keragaman jenis mangrove yang ada di arboretum lebih banyak dibandingkan ditegakan mangrove, tingkatan penyusun arboretum berupa pancang sehinggga diduga lebih banyak disukai jenis hama yang menyerang semai sampai pancang pada jenis mangrove. Faktor abiotik yang mempengaruhi yakni suhu dan kelembaban yang ada di tegakan, dan cenderung membentuk iklim mikro yang stabil dibandingkan di arboretum yang sengaja ditanam dan masih dalam bentuk pancang.

\section{Saran}

Perlu dilakukan kegiatan inventarisasi jenis hama pada persemaian sampai ke tegakan mangrove untuk mengetahui sebaran populasi hama pada ekosistem mangrove. Data ini dapat digunakan sebagai acuan untuk dilakukannya kegiatan preventif maupun penanggulangan ketika terjadi ledakan hama, serta untuk mengetahui perlu tidaknya dilakukan pemeliharaan yang intensif, khususnya pada persemaian mangrove maupun pada bibit yang sudah ditanam di areal bekas tebangan karena lebih rawan terserang hama dan penyakit.

\section{DAFTAR PUSTAKA}

Anwar C, Gunawan H. 2006. Peranan Ekologis dan Sosial ekonomis Hutan Mangrove dalam Mendukung Pembangunan Wilayah Pesisir. Bogor (ID): Pusat Litbang Hutan dan Konservasi Alam Bogor. 
Baskara M, Munandar A, Samingan T. 1998 Perencanaan lanskap Arboretum Sumber Brantas sebagai obyek wisata alam. Buletin Taman dan Lanskap Indonesia 1(3): 1-3.

BMKG Wilayah II Pontianak. 2009. Data Suhu Udara dan Rata-Rata Kelembaban Udara. Pontianak (ID): Badan Meteorologi Klimatologi dan Geofisika Balai Besar Wilayah II Supadio Pontianak.

Dewiyanti I, Yunita. 2013. Identifikasi dan kelimpahan hama penyebab ketidakberhasilan rehabilitasi ekosistem mangrove. Ilmu Kelautan 18(3): 153-154.

Fratini S, Vannini M, Cannici S. 2008. Feeding preference and food searching strategies mediated by air- and water-borne cues in the mudwhelk Terebralia palustris (Potamididae: Gastropoda). Journal of Experimental Marine Biology and Ecology 36(2): 26-31.

Kusmana C, Wilarso S, Hilwan I, Pamoengkas P, Wibowo C, Tiryana T, Triswanto A, Yunasfi, Hamzah. 2005. Teknik Rehabilitasi Mangrove. Bogor (ID): Fakultas Kehutanan, Institut Pertanian Bogor.

Ngatiman. 2010. Serangan hama rayap pada meranti merah (Shorea leprosula MIQ.) di Samboja. Info Teknis Dipterokarpa 4(1): 63-68.
Pemerintah Republik Indonesia. 1999. Undang-Undang Republik Indonesia Nomor 41 Tahun 1999 tentang Kehutanan. Jakarta (ID): Sekretariat Negara.

Pope GT, Tagaro SP. 2006. The new classification of gastropods according to Bouchet \& Rocroi 2005. Visaya Feb. 2006: 1-10.

Priyono A. 2010. Panduan Praktis Teknik Rehabilitasi Mangrove di Kawasan Pesisir Indonesia. Semarang (ID): KeSEMaT.

Soeroyo. 1992. Sifat Fungsi dan Peranan Hutan Mangrove. Jakarta (ID): Pusat Penelitian dan Pengembangan Oseanologi-LIPI.

Tho YP. 1992. Termites Of Peninsular Malaysia. Kuala Lumpur: Forest Research Institute Malaysia.

Wahid. 2010. Efikasi Bioinstektisida dan kombinasinya terhadap serangan hama ulat kantong Pagodiella spp. pada bibit mangrove Rhizophora spp. di persemaian. Jurnal Agroland 17(2): 162-163.

Wibisono ITC, Priyanto EB, Suryadiputra INN. 2006. Panduan Praktis Rehabilitasi Pantai: Sebuah Pengalaman Merehabilitasi Kawasan Pesisir. Wetlands International - Indonesia Program, Bogor.

Yunasfi. 2007. Permasalahn Hama, Penyakit dan Gulma dalam Pembangunan Hutan Tanaman Industri dan Usaha Pengendaliannya. Medan (ID): USU Repository. 